\title{
胎盤性性腺刺激ホルモンに対する $\mathrm{dd}$ マウスの \\ 卵巣, 子宮重量反応について
}

\author{
窪道護夫 · * 猪 貴義・鈴木勝夫 \\ （農林省動物医薬品検査所・*農林省家畜衛生試験場）
}

胎盤性性腺刺激ホルモン（HCG と略）に対する bioassay において, 卵巣, 子宮重量の変量反応は質的な卵 巣黄体血点形成反応に比較して, 反応值が連続的な数值 としてとり报える利点がある。

前報1では卵巣黄体血点形成反応を主として検討した が，この報告は HCG に対する dd マウスの卵巣, 子宮 重量反応の結果である。

性腺刺激ホルモン（GTHと略）に対するマウス卵巣重 量反応に関して, BROwN ら²) は HCG $40 \mathrm{IU}$ 皮下注射 を行なっても，マウスの卵巣は著しく大きくならないと し, $\mathrm{C}_{3} \mathrm{H}$ 系マウスは $\mathrm{C}_{57} \mathrm{BL}$ 系マウスに対比して, 卵巣 の GTH 感受性は劣ると報告している。BUTT ら ${ }^{31}$ は HCG 20 1000 IU の過剩投与によるマウスの卵巣重量 平均値は $6.0 \mathrm{mg}$ 以下であり, 各 HCG 用量と卵巣重量 間に有意差は認められないとしている。

一方，GTH に対するマウス子宮重量反応に関して, Claringbold ら" は albino マウスの子宮重量反応につ いて検討し, HCG, PMSG, FSH, LH, HMG20 A など, 各 GTH 製剤は同じような反応 slope を示すと報告し, DonNelLy $5^{5)}$ も HCG, PMSG に対するマウス子宮重 量反応について, SW, TO, CBA, AW, $\mathrm{C}_{3} \mathrm{H}$ などの近 交系マウスの用量反応直線の slope に差はないと報告し

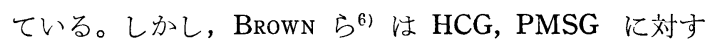
るマウス子宮重量反応について, マウスの系統により用 量反応直線の slope は異なることを立証している。

西川 $5^{7)}$ ，Evans ら $5^{8)}$ は GTH 測定にマウスの子宮 重量反応を用い，対照子宮重量の $100 \%$ 重量增加を陽性

Uterine and ovarian weight response of dd mice on chorionic gonadotropin.

Kuвomichi, Morio, Takayoshi INo* \& Katsuo SuzukI (National Veterinary Assay Laboratory \&

*National Institute of Animal Health, Tokyo)

Jap. J. Animal Reprod. 13 (4), 1967.
反応としている。西川らの用いた対照マウス子宮重量平 均值は $5.83 \mathrm{mg}$, Evans】らの用いた対照マウス子宮重 量平均值は $15 \mathrm{mg}$ であり, 用いたマウスの違いによっ て無処置対照群においてもかなりの相違がある。

以上, 各研究者によって報告された GTH に対するマ ウスの卵巣, 子宮重量反応は, マウスの系統, ホルモン 用量, 用いたホルモンの種類などによって異なった結果 が得られ，一致した結論が得られていない。これらのこ とは，今後，GTH に対する bioassay を進めるにあた って，基礎的な検討の必要であることを示しているとみ られる。

著者らは HCG に対する bioassay の基礎的資料を得 る目的で, 約 21 日令, 体重 $8.0 \sim 9.0 \mathrm{~g}$ 前後の $\mathrm{dd}$ マ ウスの卵巣, 子宮重量反応について次の項目について検 討を行なった。

(1) 卵巣, 子宮の新鮮重量と固定重量の関係. HCG の bioassay では同時に多数例の材料を扱う場合が多い ので，方法の簡便化が可能であるかどうかを調べるため に新鮮材料を固定した時においても, 検定結果において 新鮮材料の場合と同様の傾向が得られるかどうかについ て調べた。(2) 卵巣重量反応.（3）子宮重量反応．（4） 卵巣黄体血点形成反応. 卵巣, 子宮重量反応を調べた材 料と同一材料について, 卵巣黄体血点形成反応と同時に 調べたが，これは前報1)で得られた結果と比較するため に行なった。(5) 反復実験による再現性の検討などであ る。

\section{実験材料と方法}

材料：HCG 国際単位 (IU) の標準品を滅菌生理食塩 液で溶解稀釈し, 各濃度のホルモン溶液になるように調 製した。このホルモン溶液を試験直前に調製し, 試験期 間中は $0 \sim 5^{\circ} \mathrm{C}$ に保存した。

動物：dd 幼若雌マウスの約 21 日令の健康マウスで 
体重 $8.0 \sim 9.0 \mathrm{~g}$ 前後のものを使用した。

方法：各濃度のホルモン溶液を各試験群のマウス 1 匹 につき $0.1 \mathrm{ml}$ ずつ 1 日 2 回 2 日間計 4 回 $0.4 \mathrm{ml}$ を腹部皮下に注射した。各試験群における HCG の注射 総量は $0.1,0.3,0.5,1.0,1.5,3.0,4.5,6.0,8.0$ の各 IU のホルモン量である。第 1 回注射後 100 時間 目に剖検を行ない, 卵巣, 子宮の重量, 卵巣黄体血点形 成反応などを検査した。なお, 卵巣, 子官の解剖時にお ける重量を新鮮重量とし, 新鮮重量測定後, これらの材
料をブアン氏液で 24 時間浸し, さらに $70 \%$ アルコー ルで 2〜4 時間脱水後秤量し，これを固定重量とした。 子宮重量については解剖時において子宮内貯溜水をと り除いて測定した。また得られた卵巣, 子宮の新鮮重量 と固定重量については, 処理法の違いによる測定值の安 定性について調べるため相関と回帰を求めた。 HCG の 各ホルモン用量に対する卵巣, 子宮重量反応については 新鮮重量, 固定重量について統計的処理方法を用いて検 討した。
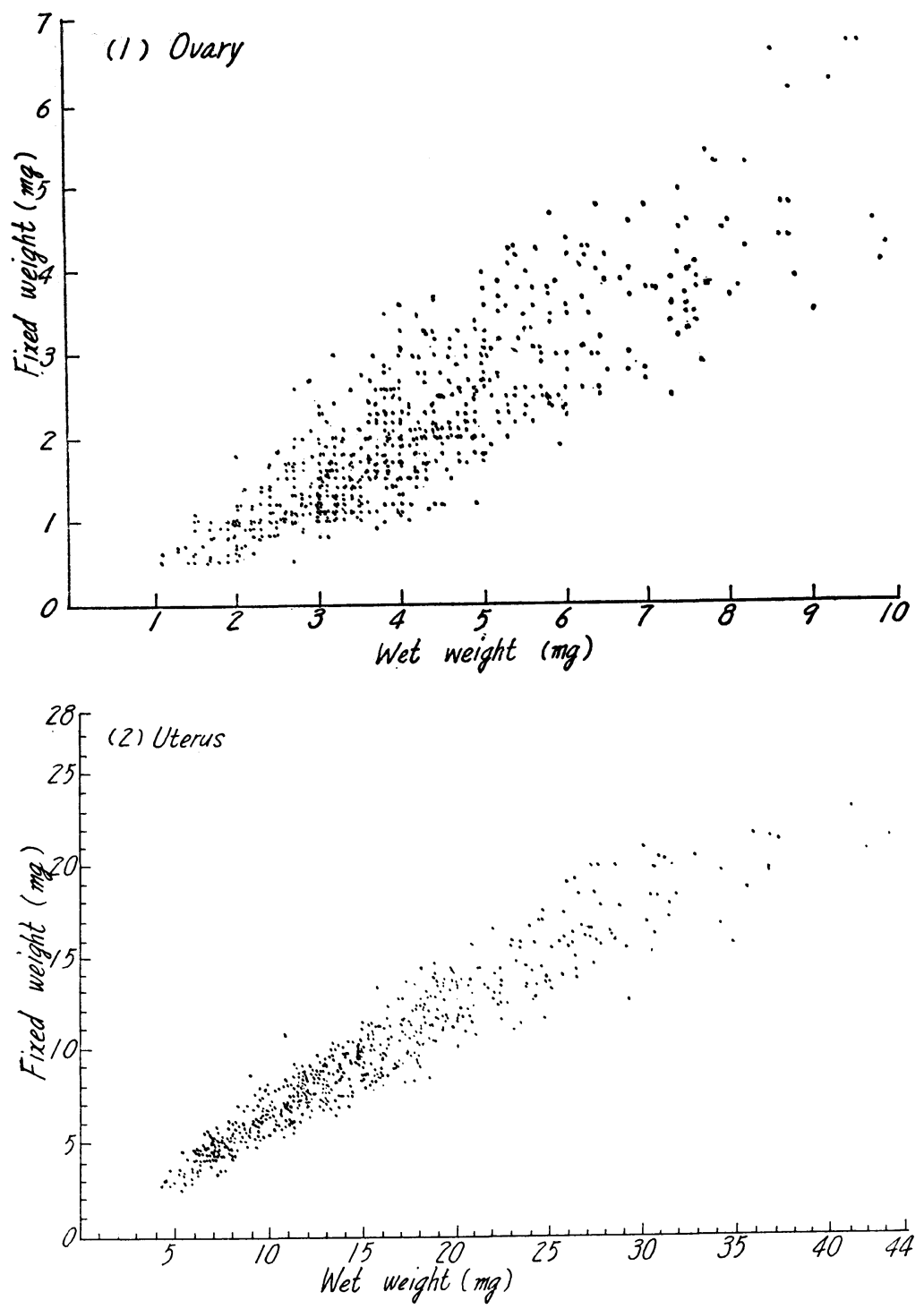

Wet. $\mathrm{W}=(\mathrm{X})$

Fix. $\mathrm{W}=(\mathrm{Y})$ $r=0.894$

$\mathrm{t}_{(48)}=13.825 \mathrm{P}=0.001^{* *}$

$\mathrm{Y}=0.66 \mathrm{x}-0.6294$

$\frac{\mathrm{b}}{\sqrt{\mathrm{v}(\mathrm{b})}}=16.75 \quad \mathrm{P}=0.001^{* *}$ $\mathrm{X}=1.19 \mathrm{y}+1.6267$ $\frac{\mathrm{b}}{\sqrt{\mathrm{v}(\mathrm{b})}}=30.00 \quad \mathrm{P}=0.001^{* *}$
Wet. $\mathrm{W}=(\mathrm{X})$

Fix. $W=(Y)$

$\mathrm{Y}=0.58 \mathrm{x}+0.4230 \quad \mathrm{r}=0.954$

$\frac{\mathrm{b}}{\sqrt{\mathrm{v}(\mathrm{b})}}=29.50 \quad \mathrm{P}=0.001^{* *}$

$\mathrm{t}_{(48)}=22.105$

$\mathrm{X}=1.55 \mathrm{y}+0.6725$

$\mathrm{P}=0.001^{* *}$

$\frac{\mathrm{b}}{\sqrt{\mathrm{v}(\mathrm{b})}}=77.50 \quad \mathrm{P}=0.001^{* *}$

Fig. 1. Correlation figure of wet weight and fixed weight of ovary and uterus. 


\section{実験成績}

1）材料の処理法の違いと測定值の安定性について 卵巣および子宮の処理法の違いによる測定值の变動を 新鮮重量, 固定重量で検討した。Fig. 1 は卵巣および 子宮の新鮮重量と固定重量との相関関係を示したもので ある。Fig. 1 に示されているようにいずれも正の相関 が認められる。この全体の材料の中から無作為に 50 例 ずつ抽出し, 卵巣と子宮の新鮮重量と固定重量の相関係 数, その有意性の検定, 回帰, 回帰係数の有意性の検定 を行なった。

卵巣での相関倸数は $\mathrm{r}=0.894$, 子宮では $\mathrm{r}=0.954$ で それぞれの $\mathrm{r}$ の有意性峐く, $\mathrm{p}=0.001$ を示した。卵 巣, 子宮の新鮮重量と固定重量の間には順相関のあるこ とが認められた。卵巣および子宮の新鮮重量と固定重量 について回帰を求めたところ, 卵巣での新鮮重量から得
られる固定重量の回帰直線は $\mathrm{Y}=0.66 \mathrm{x}-0.629$, 固定重 量から得られる新鮮重量の回帰直線は $\mathrm{X}=1.9 \mathrm{y}+1.627$ であった。子宮での新鮮重量から得られる固定重量の回 帰直線は $\mathrm{Y}=0.58 \mathrm{x}+0.423$, 固定重量から得られる新鮮 重量の回帰直線は $\mathrm{X}=1.55 \mathrm{y}+0.673$ であった。それぞ れの回帰直線について回帰係数の有意性の検定を行なっ たところ，それぞれの P は 0.001 で高い有意性を示し た。また相関係数の高い子宮について新鮮重量, 固定重 量の回帰直線から得られる理論值を求めたところ, 新鮮 重量は 5 32 mg, 固定重量は 3 20 mg の重量範囲に おいて，実測值と同じ傾向を示す值が得られることが認 められた。したがって, 卵巣, 子宮重量では剖検時に多 数新鮮材料の処理が不可能の時には，固定した材料を用 いても新鮮材料と同様の傾向を示す結果が得られるもの と考える。

2) 卵巣重量反応について

Table 1. The ovarian and uterine weight reaction in dd mice injected with HCG (1) Ovarian weight reaction

\begin{tabular}{c|c|cc|r|rr}
\hline \hline $\begin{array}{l}\text { Hormone } \\
\text { dose }\end{array}$ & $\begin{array}{l}\text { No. of } \\
\text { mice }\end{array}$ & \multicolumn{2}{|c|}{ Wet weight $(\mathrm{mg})$} & $\begin{array}{l}\text { No. of } \\
\text { mice }\end{array}$ & \multicolumn{2}{c}{ Fixed weight (mg) } \\
\hline $\mathrm{NaCl}$ & 97 & $3.83 \pm 0.29$ & $(4.12-3.54)$ & 134 & $2.30 \pm 0.18$ & $(2.48-2.12)$ \\
$0.1 \mathrm{IU}$ & & & & 15 & $3.15 \pm 0.54$ & $(3.63-2.61)$ \\
$0.3 \mathrm{IU}$ & & & 15 & $3.53 \pm 0.42$ & $(3.95-3.11)$ \\
$0.5 \mathrm{IU}$ & 99 & $4.00 \pm 0.31$ & $(4.31-3.69)$ & 131 & $2.48 \pm 0.21$ & $(2.69-2.27)$ \\
$1.0 \mathrm{IU}$ & 86 & $4.28 \pm 0.37$ & $(4.65-3.91)$ & 134 & $2.61 \pm 0.21$ & $(2.82-2.40)$ \\
$1.5 \mathrm{IU}$ & 89 & $3.81 \pm 0.32$ & $(4.13-3.49)$ & 132 & $2.25 \pm 0.19$ & $(2.44-2.06)$ \\
$3.0 \mathrm{IU}$ & 89 & $4.21 \pm 0.38$ & $(4.59-3.83)$ & 131 & $2.41 \pm 0.22$ & $(2.63-2.19)$ \\
$4.5 \mathrm{IU}$ & 89 & $4.66 \pm 0.34$ & $(5.00-4.32)$ & 127 & $2.55 \pm 0.21$ & $(2.76-2.34)$ \\
$6.0 \mathrm{IU}$ & 89 & $4.62 \pm 0.42$ & $(5.04-4.20)$ & 132 & $2.79 \pm 0.23$ & $(3.02-2.56)$ \\
$8.0 \mathrm{IU}$ & & & & 15 & $3.37 \pm 0.34$ & $(3.71-3.03)$ \\
\hline
\end{tabular}

(2) Uterine weight reaction

\begin{tabular}{|c|c|c|c|c|c|c|}
\hline $\begin{array}{l}\text { Hormone } \\
\text { dose }\end{array}$ & $\begin{array}{l}\text { No. of } \\
\text { mice }\end{array}$ & \multicolumn{2}{|c|}{ Wet weight (mg) } & $\begin{array}{l}\text { No. of } \\
\text { mice }\end{array}$ & \multicolumn{2}{|c|}{ Fixed weight (mg) } \\
\hline $\mathrm{NaCl}$ & 98 & $9.72 \pm 0.62$ & $(10.34-9.10)$ & 135 & $6.12 \pm 0.32$ & $(6.44-5.80)$ \\
\hline $0.1 \mathrm{IU}$ & & & & 15 & $5.72 \pm 1.24$ & $(6.96-4.48)$ \\
\hline $0.3 \mathrm{IU}$ & & & & 15 & $6.07 \pm 0.63$ & $(6.70-5.44)$ \\
\hline $0.5 \mathrm{IU}$ & 99 & $11.18 \pm 0.66$ & $(11.84-10.52)$ & 131 & $6.87 \pm 0.33$ & $(7.20-6.54)$ \\
\hline $1.0 \mathrm{IU}$ & 86 & $12.85 \pm 0.99$ & $(13.84-11.86)$ & 134 & $8.63 \pm 0.54$ & $(9.17-8.09)$ \\
\hline $1.5 \mathrm{IU}$ & 89 & $13.67 \pm 1.15$ & $(14.82-12.52)$ & 132 & $8.19 \pm 0.56$ & $(8.75-7.63)$ \\
\hline $3.0 \mathrm{IU}$ & 89 & $16.79 \pm 1.34$ & $(18.13-15.45)$ & 131 & $10.52 \pm 0.64$ & $(11.16-9.88)$ \\
\hline $4.5 \mathrm{IU}$ & 89 & $19.47 \pm 1.50$ & $(20.97-17.97)$ & 127 & $11.86 \pm 0.71$ & $(12.57-11.15)$ \\
\hline $6.0 \mathrm{IU}$ & 88 & $20.99 \pm 1.75$ & $(22.74-19.22)$ & 131 & $13.28 \pm 0.80$ & $(14.08-12.48)$ \\
\hline $8.0 \mathrm{IU}$ & & & & 15 & $14.33 \pm 3.03$ & $(17.36-11.30)$ \\
\hline
\end{tabular}

Notes : Weight $=$ Mean weight $\pm 95 \%$ Confidence limit 

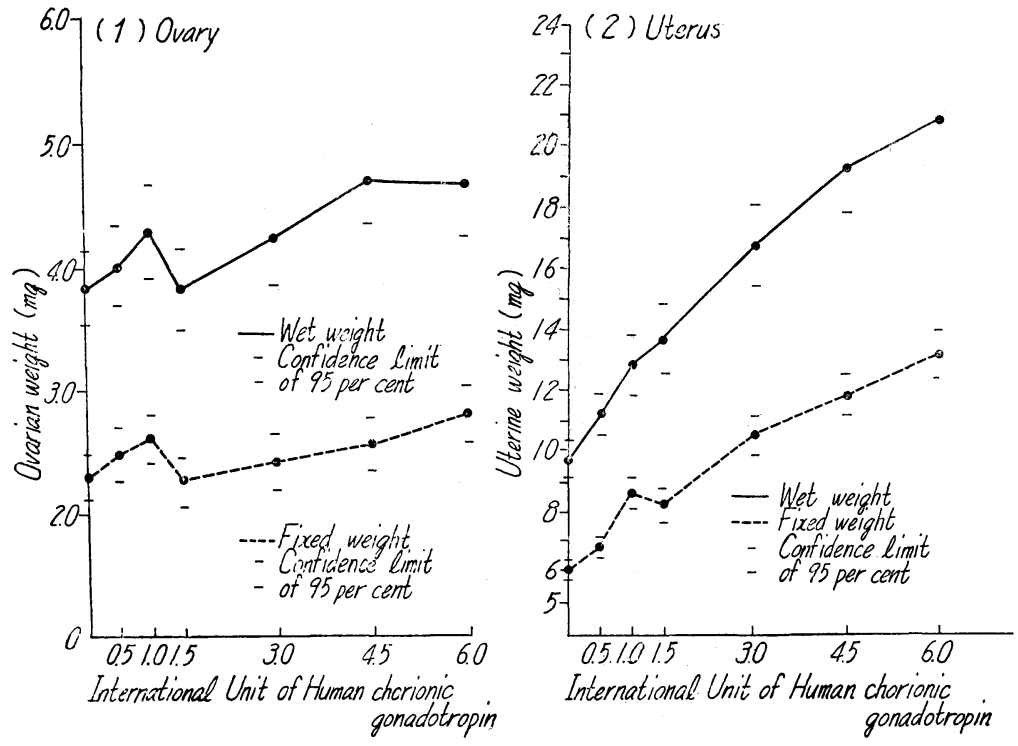

Fig. 2. The dose response curve of ovarian and uterine weight reaction in dd mice injected with $\mathrm{HCG}$.

Table 1 (1) Fig. 2 (1) は卵巣重量反応について, 各 ホルモン用量に対して供試したマウス数と新鮮重量, 固 定重量の平均値と $95 \%$ 信頼限界を示したものである。 Table 1 (1) 中における括弧内の数字は $95 \%$ 信頼限界の 上限と下限の範囲を示す。Table 1 (1) Fig. 2 (1)に示 されているように新鮮重量，固定重量ともに $1.0 \mathrm{IU} て ゙$

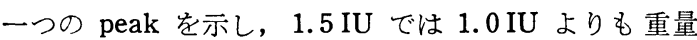
の減少， $1.5 \mathrm{IU}$ 以後ではゅるやかな上昇曲線を示した が， 4.5 IU 以上になると HCG の量的增加にもかかわ らず，卵巣新鮮重量平均值は $5 \mathrm{mg}$ 以上にならなかっ た。

次いで，各ホルモン用星に対する卵巣重量平均值につ いて差の検定を行なった結果, 新鮮重量では $\mathrm{NaCl}: 4.5$ IU, $\mathrm{NaCl}: 6.0 \mathrm{IU}, 0.5 \mathrm{IU}: 4.5 \mathrm{IU}, 0.5 \mathrm{IU}: 6.0 \mathrm{IU}$, $1.5 \mathrm{IU}: 4.5 \mathrm{IU}, 1.5 \mathrm{IU}: 6.0 \mathrm{IU}$ 問で有意差がみられた が，他の用量䦌では有意差は得られなかった。また，固 定重量については $\mathrm{NaCl} ： 1.0 \mathrm{IU}, \mathrm{NaCl}: 6.0 \mathrm{IU}, 1.0$ IU : $1.5 \mathrm{IU}, 1.5 \mathrm{IU}: 4.5 \mathrm{IU}, 1.5 \mathrm{IU}: 6.0 \mathrm{IU}, 3.0 \mathrm{IU}$ : 6. $0 \mathrm{IU}$ 閒で有意差がみられたが，他の用量間において は有瑟㾏は得られなった。

3）子宮重量反応について

HCG に対する dd マウスの子宮重量反応について， 各ホルモン用量に対して供試したマウス数と新鮮重量, 固定重量の平厸値と $95 \%$ 信頼限界を Table 1(2), Fig. 2 (2) に示した。Table 1（2）中における括弧内の数字
は $95 \%$ 信頼限界の上限と下限の範囲を示す。 Table 1 (2), Fig. 2 (2) に示されているように，子宮の新鮮重 量においてはホルモン用量が $0.5 \mathrm{IU}, 1.0 \mathrm{IU}, 1.5 \mathrm{IU}$, 3. $0 \mathrm{IU}, 4.5 \mathrm{IU}, 6.0 \mathrm{IU}$ と高まるに伴ない漸增している ことがみられ，0.5〜6.0 IU の用量範囲において，ホル モン用量に対し一定傾向を示す反応曲線が得られた。一 方, 固定重量においては $1.5 \mathrm{IU} て ゙$ 卯巣重量反応でみら れたような重量値の滅少があったが，3.0 IU，4.5 IU， 6.0 IU の用量範囲では一定傾向を示す反応曲線が得ら れた。

次いで，各ホルモン用量に対する子宮重量について， 平均値の差の検定を行なった結果, 新鮮重量, 固定重量 ともに, $1.0 \mathrm{IU}: 1.5 \mathrm{IU}, 4.5 \mathrm{IU}: 6.0 \mathrm{IU}$ の関係を除く 他の用量開でいずれも高い有意差が得られた。したがっ て，HCG に対する子宮重量反応は卵栄重量と異なり, ホルモン用量に刘する重量増加の高いことが認められ た。

そこで， HCG 0.5〜6.0 IU の範囲の用量に対する子. 宮重量反応の回帰直線を新鮮重量, 固定重量で求めた。 その結果を Fig. 3 に示す。ホルモン用量から得られる 新鮮重量の回帰直線は $\mathrm{Y}=1.88 \mathrm{x}+10.522$, 新鮮重量か ら得られるホルモン用量の回帰直線は $\mathrm{X}=0.52 \mathrm{y}-5.418$. であった。固定重量から得られる゙ホルモン用量回帰直線 は $\mathrm{X}=0.83 \mathrm{y}-5.402$, ホルモン用量から得られる固定重 量回帰直線は $\mathrm{Y}=1.16 \mathrm{x}+6.626$ であった。それぞれの 


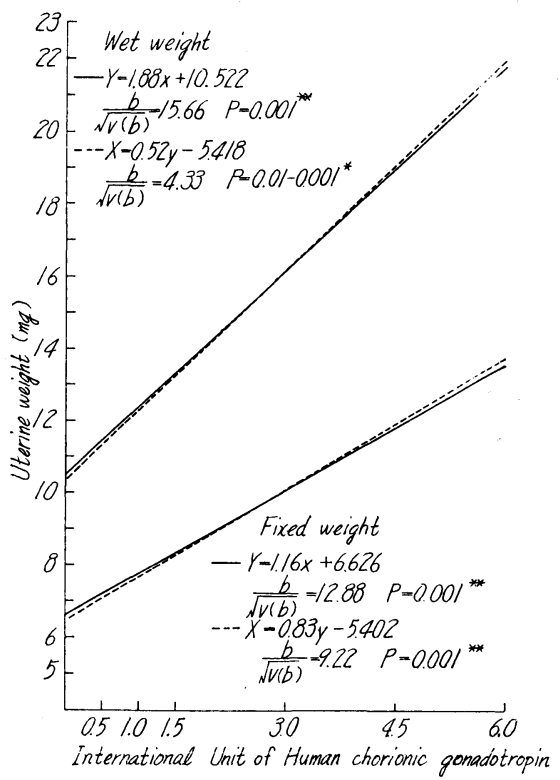

Fig. 3. The dose response lines of uterine weight reaction in dd mice injected with HCG.

回帰直線の回帰係数の有意性の検定を行なったところ， それぞれの P は 0.01〜0.001 で高い有意性を示した。 また, 各ホルモン用量から得られる子宮重量の実測值と 理論値, 子宮重量から得られるホルモン量の理論値と実 測値の適合することが認められた。

4) 卵巣黄体血点形成反応について 前報1)で得られた結果と比較するために，(3)，(4)の
卵巣，子宮重量反応を調べたのと同一材料で卵巣黄体血 点形成反応について検討した。

Table 2 は各ホルモン用量に対するマウス数と注射 時, 解剖時の体重平均值と標準偏差, 卵巣黄体血点形成 反応陽性率を示したものである。Table 2 に示されてい るように反応陽性率はホルモンの增加に伴ない高まる傾 向にあるが， $4.5 \mathrm{IU}$ でほぼ反応の頂上に達し，6.0 IU， $8.0 \mathrm{IU}$ でその反応曲線は横這いとなった。また， 1.0 IU 以下では反応陽性率は極めて低く, $1.0 \sim 4.5 \mathrm{IU} の$ 用量範囲においては一定傾向を示す用量反忘曲線が得ら れた。各ホルモン用量と反応陽性率について $\chi^{2}$-test で検討したところ， $0.5 \mathrm{IU}: 1.0 \mathrm{IU}, 4.5 \mathrm{IU}: 6.0 \mathrm{IU}$, $4.5 \mathrm{IU}: 8.0 \mathrm{IU}, 6.0 \mathrm{IU}: 8.0 \mathrm{IU}$ 以外の用量間におい ていずれも高い有意差が得られた。この実験結果は前 報1)で報告した卵巣黄体血点形成反応の成績とほぼ同様 の傾向を示した。

5） 反復実験による反忘の再現性について

次に反復実験による反忘の再現性について, 子宮重量 反応と卯巣黄体血点形成反応について検討した。その結 果をTable 3 に示す。これらの実験の実施期間は 6〜7 月 の約 1 力月間である。子宮重量反応では新鮮重量につい て分散分析を行ない, 卵巣黄体血点形成反応で注 $\chi^{2}-$ test で検討した。 HCG $0.5 \sim 6.0 \mathrm{IU}$ に対する子宮の 新鮮重量反応について反復実験し, その繰り返しによる 有意性を検討したところ，反応值に有意差は得られなか った。卵巣黄体血点形成反応について, 1.5〜6.0 IU の4 用量で 10 回の反復実験を行なったところ, 繰り返しによ る反応性の有意差は得られなかった。したがって,この実

Table 2. Mean body weight and positive rate of hemorrhagic follicles and corpora lutea formation reaction in dd mice injected with $\mathrm{HCG}$

\begin{tabular}{|c|c|c|c|c|c|}
\hline \multirow{2}{*}{$\begin{array}{l}\text { Hormone } \\
\text { dose }\end{array}$} & \multirow{2}{*}{$\begin{array}{l}\text { No. of } \\
\text { mice }\end{array}$} & \multicolumn{2}{|c|}{ Body weight } & \multirow{2}{*}{\multicolumn{2}{|c|}{$\begin{array}{l}\text { Hemorrhagic follicles and } \\
\text { corpora lutea formation } \\
\text { reaction }\end{array}$}} \\
\hline & & at injection & at dissection & & \\
\hline $\mathrm{NaCl}$ & 135 & $8.75 \pm 0.19$ & $11.45 \pm 1.37$ & $0 / 135$ & 0 \\
\hline $0.1 \mathrm{IU}$ & 15 & $8.91 \pm 0.48$ & $12.29 \pm 0.88$ & $0 / 15$ & 0 \\
\hline $0.3 \mathrm{IU}$ & 15 & $8.67 \pm 0.44$ & $12.13 \pm 0.71$ & $0 / 15$ & 0 \\
\hline $0.5 \mathrm{IU}$ & 131 & $8.71 \pm 0.18$ & $11.38 \pm 1.48$ & $3 / 131$ & 2.3 \\
\hline $1.0 \mathrm{IU}$ & 134 & $8.73 \pm 0.18$ & $11.58 \pm 1.30$ & $23 / 134$ & 17.2 \\
\hline $1.5 \mathrm{IU}$ & 132 & $8.68 \pm 0.16$ & $11.49 \pm 1.11$ & $38 / 132$ & 28.8 \\
\hline $3.0 \mathrm{IU}$ & 131 & $8.70 \pm 0.18$ & $11.46 \pm 1.11$ & $89 / 131$ & 67.9 \\
\hline $4.5 \mathrm{IU}$ & 127 & $8.70 \pm 0.18$ & $11.70 \pm 1.04$ & $106 / 127$ & 83.5 \\
\hline $6.0 \mathrm{IU}$ & 132 & $8.67 \pm 0.20$ & $11.60 \pm 1.27$ & $118 / 132$ & 89.4 \\
\hline $8.0 \mathrm{IU}$ & 15 & $8.77 \pm 0.36$ & $11.94 \pm 0.97$ & $14 / 15$ & 93.3 \\
\hline
\end{tabular}

Notes : Body weight $=$ Mean weight \pm standard deviation 
Table 3. Analysis of variance of uterine wet weight reaction and hemorrhagic follicles and corpora lutea formation reaction in dd mice

(1) Uterine wet weight reaction

\begin{tabular}{l|r|r|r|r|r}
\hline \hline Factor & SS & N & SS/N & F & P \\
\hline Hormone & 810.2240 & 6 & 135.0373 & 29.2706 & $0.001^{* *}$ \\
Time & 171.1454 & 6 & 2.8524 & 0.6182 & 0.20 \\
Error & 166.0828 & 36 & 4.6134 & & \\
Total & 1147.4522 & 48 & & & \\
\hline
\end{tabular}

(2) Hemorrhagic follicles and corpora lutea formation reaction

\begin{tabular}{c|r|c}
\hline \hline Hormone dose & \multicolumn{1}{|c|}{$\chi^{2}(9)$} & $\mathrm{P}$ \\
\hline $1.5 \mathrm{IU}$ & 4.994 & $0.9-0.8$ \\
$3.0 \mathrm{IU}$ & 11.291 & $0.3-0.2$ \\
$4.5 \mathrm{IU}$ & 7.529 & $0.7-0.5$ \\
$6.0 \mathrm{IU}$ & 4.743 & $0.9-0.8$ \\
\hline
\end{tabular}

Notes : $\mathrm{P}=$ Probability

験の実施期間中に行なった子宮重量反応, 卵巣䔬体血点 形成反応は反復実験による再現性があるものと考える。

\section{考察}

著者らは dd マウスの卵巣, 子宮の処理と測定値の安 定性について, 新鮮重量と固定重量の関係で検溯した結 果, 卵巣, 子宮の新鮮重量と固定重量との問には顺相関 のあることが明らかとなった。また子宮の新鮮重量と固 定重量との回帰直線から得られ理論值は実測值に対比し て, ある一定の重量範囲において適合することが涊めら れた。British Pharmacopoeia ${ }^{9)}$ は HCG に対するラッ トの卵巣重量法では卵巣をブアン氏液で固定してアル コールで処理後称量しているが，今回の成續から HCG 製剂の生物榆定において, 多数例の新鮮忉料の処理が時 間的に不可能のとき，固定して测定することも一つの方 法と考える。

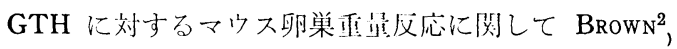
は FSH 測定で検别し， HCG $40 \mathrm{IU}$ 攴下注射を行なっ てもマウスの卵巣は著しく大きくならないとし，マウス の系統により卵巣の GTH 感受性は異なるとしている。 ButT ら ${ }^{3)}$ は HCG 20 1000 IU の遄剩投与によるマウ スの卵巣重量平均值は $6.0 \mathrm{mg}$ 以下であり, 各 $\mathrm{HCG}$ 用 量と卵巣重量間には $\mathrm{t}=1.08, \mathrm{P}>0.10$ で有意差を涩め ないと報告している。

著者らの各 HCG 用量に対する dd マウスの卵巣重量
反応においては $1.0 \mathrm{IU}$ で一つの peak を示し, $1.5 \mathrm{IU}$ で著しく減少し, それ以後はゆるやかな上昇曲線を描く 変化を示した。4.5〜6.0 IU になると HCG の量的増加 にもかかわらず, 卵巣新鮮重量平均值は $5 \mathrm{mg}$ 以上には ならなかった。この実験結果からマウス卵巣重量反応は HCG 1.5 IU を境として, 異なる二相性の反応曲線から なることが明らかとなった。このことは HCG の低用 量, 高用量に対するマウス卵巣重量の反応性が異なって くると考えられる。なお， 1.5 IU で卵巣重量の減少す る要因を解析するため卯巣重量と卵巣黄体血点形成反応 について検討したが, 卵巣黄体血点形成反忘陽性群と陰 性群の卯巣重量間に有意差は認められなかった。この $1.5 \mathrm{IU}$ における卵巣重量減少の機構は HCG に対する 生体のより本質的な反応と考えられる。また，HCG 用 量と卵巣重量平均値の差の検定においてもかなりのホル モン用量比でないと有意差はなく，ホルモン投与量と用 量反応が，この実験に羘いた dd マウスでは平行関係を 示さないことふら, dd マウスの卵巣重量反応は HCG の生物検定法に適さないと考える。しかし，HCG に対 しマウス卵䍒重量が著しく大きくならないことは, LAMOND ら ${ }^{10)}$ も指搁しているょうに, HCG 製剂中の HCG 以外のマウス卵巣重星を增加さすホルモン性物質 の検出に役立つと考えられる。

一方，マウス子宫重量反応に閂して， dd マウスを用 いて検討した結果， HCG 0.5〜6.0 IU において，ホル モン用量の高まるに件ない, マウス子宮重量の漸増する ことが称められ，統哃的にも $1.0: 1.5,4.5: 6.0 \mathrm{IU} の$ 関係を除く他の川细田で，いずれも高い有意差を示すこ とが明らかとなった。この事实は HCG に対し dd マウ スの卵柴から分泌される子空重星増加物質が， HCGの

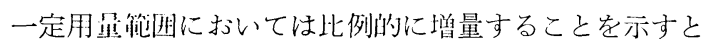
考えられる。また HCG 0.5〜6.0 IU の用量に対するマ ウス子宫杖量反态の回州直線については回州の有意性は 高く, 回㫦直線から算出される理渝值は实测値と一定の 重量範冉に才いて一致することが羿められた。したが

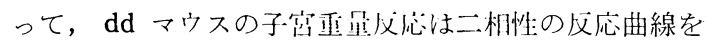
示した卵栄再量反応と潩なり，HCG の一定用量に対 して定量的に增加する反応であると考える。

Claringbold 5 $5^{4)}$, Donnelly $ら^{5)}$ は各種 GTH 製剂 に対するマウス子宮重量反応について, 各系統マウスを 用いて検叶し, マウス子宮重量反志は系統間, 各 GTH 製剤間で用量反応直線の slope に差はないと報告し， BROWN ら ${ }^{6)}$ は HCG, PMSG に対するマウス子宮重量 反応直線の slope は実験に供するマウスの種類により 
異なるとしているが，この実験結果が示すようにマウス の系統を一定にし，日令，体重を均一化する，いわゆる 実験動物の条件を整えることによって，マウス子宮重量 反応は HCG の生物学的力価検定法に採用できるものと 考光る。

次に同一材料における卵巣黄体血点形成反応につい て，前報1)の成績と比較するため検討した結果， HCG 用量に対する反応陽性率ならびに $\chi^{2}$-test による有意性 検定において，前報の成績とほぼ同様の傾向を示す結果 が得られた。前報1) の実験期間は 11〜1月の冬期であ り，今回の実験は 6〜7 月の夏期であるが, HCG の一 定用量に対する $\mathrm{dd}$ マウスの反応陽性率がほぼ同様の傾 向を示すことは注目すべきと考える。しかし，夏期の反 応陽性率に対比して, 冬期の反応陽性率注全体的に低 く, 試験マウスの環境条件が HCG 反応性に大きい影響 を及ぼしていることが推察される。

著者らは子宮重量反応, 卵巣黄体血点形成反応につい て, 実験の繰り返しによる反応の再現性を検討した結 果, 両反応とも実験の反復により有意差を示さないこと が明らかとなった。したがって，マウス子宮重量反応， 卵巣黄体血点形成反応は再現性のある反応と考えられ る。しかし，これらの結果はある一定期間において得ら れた結果であるので，長期間にわたっての実験で，反応 の再現性が得られるかどうか今後さらに検討を加える予 定である。

\section{要 約}

HCG の生物学的検定法を検討する目的で約 21 日令 の dd マウスの卵巣, 子宮重量反応について検討した結 果, 次の成績が得られた。

1) HCG に対する dd 幼若雌マウスの卵巣と子宮の 重量反応で, 新鮮重量と固定重量との間には順相関が認 められた。卵巣での相関係数は 0.894 , 子宮での相関係 数は 0.954 で, それぞれの相関倸数のP 0.001 で高 い有意性を示した。また卵巣, 子宮の新鮮重量, 固定重 量について回帰直線を求め, 回帰係数の有意性を検討乙 たところ，Pは 0.001 で高い有意性を示すことが明ら かとなった。これらの結果から剖検時に多数の新鮮材料 の測定が不可能のとき, 固定して測ることも一つの方法 とみられる。

2) HCG 0.5 6.0 IU に対するマウス卵巣重量は新 鮮重量, 固定重量ともに $1.0 \mathrm{IU}$ で一つの peak を示 し, $1.5 \mathrm{IU}$ では $1.0 \mathrm{IU}$ よりも重量の減少, $1.5 \mathrm{IU}$ 以 後では河るやかな上昇曲線を示したが， $4.5 \mathrm{IU}$ 以上に
なると HCG の量的増加にもかかわらず卵巣重量平均值 は $5 \mathrm{mg}$ 以上にはならなかった。この実験結果からマウ ス卵巣重量反応は HCG $1.5 \mathrm{IU}$ を境として異なる二相 性の 反応曲線からなることが明らかとなった。また， HCG 用量と卵巣重量増加は平行関係を示さないことか ら, dd マウスの卵巣重量反応は HCG の生物検定法に 適さないことが認められた。

3） dd マウスの子宮重量反応は卵巣重量反応とは異 なり, HCG 0.5 6.0 IU の用量範囲において, HCG 用量の高まるに伴ない子宮重量法漸增し，一定傾向を示 す反応曲線が得られた。各ホルモン用量間における子宮 重量の平均値について差の検定を行なったところ, 1.0 : 1.5，4.5:6.0 IUの関係を除く他の用量間でいずれも有 意差が得られた。また，HCG 0.5〜6.0 IU においては回 帰直線が成立し, 回帰係数の有意性検定においても $\mathrm{P}$ は 0.01〜0.001で高い有意性を示すことが明らかとなった。

4) HCG に対する卵巣黄体血点形成反応について前 報1)で得られた成績と比較するため検討した結果, 卵巣 黄体血点形成反応陽性率は HCG 用量の增加に伴ない高 まる傾向にあるが，4.5 IU でほぼ反応の頂上に達し， 6.0 $8.0 \mathrm{IU}$ でその反応曲線は横這いとなった。また $1.0 \mathrm{IU}$ 以下では反応陽性率は極めて低く, $1.0 \sim 4.5 \mathrm{IU}$ の用量範囲において一定傾向を示す用量反応曲線が得ら れた。この実験成績は前報1で報告した卵巣黄体血点形 成反応の成績とほぼ同様の傾向を示した。

5）反復実験による反応の再現性について子宮重量反 応, 卵巣黄体血点形成反応で検討したところ, 両反応と も測定の繰り返しによる有意差は得られなかった。した がって, HCG に対する dd マウスの子宮重量反応, 卵 巣黄体血点形成反応は再現性のある反応とみられる。

本研究の機会を与兄られた川島秀雄前動薬検所長（現 東京農大 教 授), 農林省家畜衛生試験場藤田墛吉場長, 動薬検信藤謙蔵所長に感謝いたします。また, 種々有益 なご助言とご批判を賜わった農林省家畜衛生試験場須藤 恒二博士に深謝いたします。

(1967. 6. 20 受付)

\section{文献}

1）等道 (護) - 猪（貴) ・ 鈴木 (勝): 本誌, 13, 103, 1967. 2) Brown, P.S \& M. Wells: J. Endocrinol. 35, 99, 1966. 3) Butt, W.R, A.C. СRоoKe, J.D. Ingram \& B.P. Round: J. Endocrinol. 16, 107, 1957. 4) Claringbold. P.J.\& D.R. Lamond: J. Endocrinol. 16, 86, 1957. 5) Donnelly, R.B. G.M. 
Stone: J. Endocrinol. 21, 459, 1961. 6) Brown, P.S., E.J. Cunningham, R.P. Finegan: J. Endocrinol. 18, 191, 1959. 9) 西川(光) - 屋形(稔) - 会田 (正): 日本内分泌学会誌, 37, 594, 1961. 8) Evans et al:
最も新しいホルモン検査法(伊藤四十二編集)協同医書， 62, 1956. 9) British Pharmacopoeia VIII, 814, 1953. 10) Lamond, D.R: J. Endocrinol. 17, 218, 1958.

\section{Summary}

In a recent report (1) the assay method by hemorrhagic follicles and corpora lutea forming reaction was mainly investigated.

The present paper describes the experimental results of uterine and ovarian weight response of dd mice on chorionic gonadotropin.

Following results were obtained.

1) Rank correlation was given between fresh and fixed organ weights by means of the increase in uterine and ovarian weight response of immature female dd mice to HCG. Rank correlation coefficients were 0.894 in ovaries and 0.954 in uteri, and there was a great significance at the $0.1 \%$ level of probability. It suggests that weighing procedure of fixing organs takes advantages at autopsy when there are too many fresh organs to weigh in a limitted time.

2) At the dose of 1.0 IU a peak of the dose-response curve in both fresh and fixed ovarian weight was observed. A decline in weight at $1.5 \mathrm{IU}$ and then again a moderate increase covering the dose level from $1.5 \mathrm{IU}$ to $4.5 \mathrm{IU}$ were demonstrated. The mean ovarian weight was not more than $5 \mathrm{mg}$ even when an increased dose of more than $4.5 \mathrm{IU}$ was administered, however. These results elucidated the two-phase response curve of the increase in ovarian weight of dd mice at a border dose level of 1.5 IU. The fact that no parallel relationship given between the dose levels of HCG used and its effect on the increase in ovarian weight using dd mice indicates unsuitability of bioassy.

3) On the otherhand, a dose-response line with a gradual increase trend in uterine weight of dd mice was observed with increasing HCG doses from $0.5 \mathrm{IU}$ to $6.0 \mathrm{IU}$. Test of significance on the mean uterine weight for different hormone doses exclusive of 1.0:1.5 and 4.5:6.0 IU showed that there was a significant difference. The regression line covered the dose range from 0.5 IU to 6.0 IU of HCG, and high significant evidence of regression coefficients was shown at $1-0.1 \%$ level of probability.

4) Reinvestigation was performed on hemorrhagic follicles and corpora lutea forming reaction so as to compare the result with that in previous report (1). Positive rate in hemorrhagic follicles and corpora lutea forming reaction seemed to be increasing in parallel with dose levels of HCG given. The HCG level of 4.5 IU gave almost the peak of the dose-response curve, and the flat line covered the dose range of $6.0 \mathrm{IU}$ and 8.0 IU. Considerably inactive potency was observed at the dose level below 1. $0 \mathrm{IU}$ and the dose-response curve with an increasing trend covered the dose range of 1.0-4.5 IU. These results show similar trend to those in a previous report (1) on hemorrhagic follicles and corpora lutea forming reaction.

5) No significant difference was given in uterine weight reaction and hemorrhagic follicles and corpora lutea forming reaction in repeated expriments. It seeme therefore that reactions using dd mice have reproducibility in assay of HCG. 